\title{
School violence: \\ Evidence from the economics \\ literature and related \\ disciplines
}

\section{Djily Diagne}

School violence has become a serious public health issue during the last two decades. Consequently, researchers and policy makers have made substantial efforts to understand its causes and consequences and to identify effective methods to reduce its occurrence. While psychologists and other education researchers have long been active in school violence research, the topic has really been explored by economists only in recent years. This paper presents some evidence on this issue drawn from the growing economics literature and related disciplines. It shows that the phenomenon has an adverse effect on the level of educational attainment and labour market outcomes. Hence, reducing violence at schools not only eases life for many students who suffer because of it, but should also lead to more investment in human capital. Finally, some suggestions for future research are provided.

\section{Introduction}

During the last two decades, school violence has emerged as a topic of interest in many countries around the world. Worries about the phenomenon have increased recently, due to a surge in school-based shootings like the widely publicized Columbine High School tragedy in Colorado. The prevalence of this social problem has been documented by data from numerous recent surveys and other research. According to the 2007 U.S. School Survey on Crime and Safety (U.S. Department of Education, 2007), 78 percent of American public schools experienced one or more violent incidents during the school year 2005-06. In the U.K., a recent report shows that 31 percent of children experienced bullying during childhood (Brown \& Taylor, 2008). In Switzerland, this issue has been addressed by Alsaker (2003) who showed that the extent to which victimisation occurs in the early childhood years is comparable to that in grade school and has an immensely stressful effect on young children. This pattern is not limited to these countries since many other nations are facing violent incidents in or around their schools. For example, the World Health Organization reports that 
40 percent, 38 percent and 36 percent of 13 -year-olds from 35 countries had respectively fought, bullied others, and been bullied by others at school in the preceding months (Janosz et al., 2008). As school violence has become an international focus of concern, policy makers and researchers are making substantial efforts to understand the causes and consequences of the phenomenon and to identify effective methods to reduce its occurrence (Elliot, Hamburg \& Williams, 1998). Psychologists began their scientific study of violence during the first half of the last century (Amodei \& Scott, 2002). Since then, substantial psychological knowledge has been assembled regarding the causes of violence as well as its prevention. Other social scientists, among them sociologists and education researchers have also long been active in youth violence research. However, the topic has been really explored by economists only in recent years. This gap is surprising because violence in schools constitutes an interesting topic for economic analysis for at least two reasons. First, the cost of violent behaviour to victims and to the whole society is considerable, even if it does not result in death or serious injury. A simple way to evaluate the cost of violence is to adopt an accounting perspective and add up all the direct and indirect costs from violence. These include, but are not limited to, health-care costs associated with traumas caused by violence, private security expenditures, reductions in the rates of human capital accumulation, lost productivity, the cost of emergency, worker's compensation, emotional pain and suffering, vulnerability, mistrust of others, family disruption, reduced quality of life and deterioration of neighbourhoods, etc. The indirect costs are more difficult to quantify, and the lack of statistics is probably one reason for the neglect of such evaluations. Second, school violence is also of interest to economists because it represents a potential determinant of educational achievement and labour market outcomes. If being exposed to violence adversely affects educational attainment, then the individual's employment prospects may be indirectly influenced by violence (Elliot \& Kilpatrick, 1994). School violence is closely related to two areas of existing economics literature. First, there exists a considerable amount of research exploring the economic consequences of crime dating back to the seminal work of Becker (1968). Much of this research has attempted to determine how involvement with the criminal justice system affects the labour market opportunities of criminals (Bound \& Freeman, 1992). Second, from an economic point of view, education can be regarded as a production process in which a variety of inputs are used to determine a multidimensional output. Consequently, a lengthy literature has attempted to determine the impact of school inputs (expenditures, teacher characteristics, class and school size, etc.), environmental factors (peer groups) and socioeconomic characteristics. This approach, called the "production function» model is behind much of the analysis in the economics of education since the widely cited Coleman Report (Coleman et al., 1966). In comprehensive summaries of this research, Hanushek $(1986,1997)$ finds that student outcomes are not consistently related to school inputs, but rather that families and peers are the primary deter- 
minants of performance variance. Another contentious aspect of this literature is related to the influence of class size on student achievement. While there is not consistent empirical evidence on this issue, some studies have shown that small class size is important for certain types of students, such as low-achieving students, elementary school students, and students from low socio-economic bakkgrounds (Dolan \& Schmidt, 1987). However, remarkably absent from most production function studies is the effect of school violence.

The objective of this paper is to examine some of the main issues concerning school violence from the perspective of economics and related disciplines. A literature review is provided with special emphasis on the causes of violence in general and school violence in particular and economical consequences of the phenomenon.

\section{Definitional issues}

School violence has been defined in multiple ways (Aalsma \& Brown, 2008; Farrel \& Flannery, 2006; Henry, 2000). As used in most economics studies, the term violence refers to a category of behaviour that threatens or causes physical harm to another person. This broad definition covers multiple forms of violence ranging from mild incidents like shoving and throwing objects to more serious acts such as homicide and assault. It also includes school bullying which has been the subject of public concern in many countries. According to Olweus (1993), a student is being bullied or victimised "when he or she is exposed, repeatedly and over time, to negative actions on the part of one or more other persons, and he or she has difficulty defending himself or herself.» Because bullying must be a repeated action and occur regularly over time, occasional negative behaviours or conflict are not viewed as victimization. The existence of a power imbalance between the bully and victim is also a fundamental aspect of bullying under Olweus' definition. For example, it is not bullying when there is conflict between two persons of the same physical or mental strength. Furthermore, it is common to distinguish between physical, verbal, and indirect forms of bullying. Examples of the latter category include deliberate exclusion and rumour spreading that is intended to damage someone. Sexual and racial harassment are sometimes viewed as types of bullying (Smith, Pepler, \& Rigby, 2004). Note that the definition does not explicitly include some kinds of violence, such as the «symbolic violence» of domination. Finally, it should be mentioned that school violence is not limited to the student population. For instance, an estimated 10 percent of U.S. teachers are reported being threatened by a student in the past year ("The Average Teacher», Teacher Magazine, 2002). 


\section{Macro-level and school-level conditions associated with violence}

\section{Poverty, income inequality and violence}

The level of economic development, as measured by the GDP (gross domestic product) per capita, is reported to be related to school violence. For example, Akiba et al. (2002) found that GDP is a major variable that is significantly associated with rates of school violence once national characteristics of schooling have been controlled. In a comparative study of school violence in 37 nations, they found a negative relationship between GDP per capita and school violence suggesting that this phenomenon is more prevalent in developing countries. According to the authors, this result is in line with previous studies initiated by UNESCO. Socioeconomic status (SES) indicated by the fact that the student received free school meals and by the parents' occupation may also be related to school violence (Brown \& Taylor, 2008; Ammermueller, 2007). Using data from a Local Education Authority in England, Sabates (2008) shows that reductions in poverty are associated with decreasing conviction rates for violent crime for three cohorts of young people, born between 1981 and 1983. Numerous studies using the Gini coefficient as measure of income inequality have found that countries, states, or neighborhoods that are less equal in wealth have higher rates of violent crime and homicide (Elgar et al., 2009; Gartner, 1990). A review of 34 studies on income inequality and violent crime concluded that significant associations exist between income inequality and rates of homicide, assault, rape and robbery (Hsieh \& Pugh, 1993). These findings mirror results from Kennedy, Kawachi, and Prothrow-Stith (1996), who found that state-level income inequality in the United States accounted for 52 percent of the variance in homicide rates. One explanation of why income inequality relates to violence is that inequality has a corrosive effect on social relationships and the availability of «social capital» in communities (Elgar et al., 2009). Income inequality might also increase social distance between individuals and foster a harsh social environment that is rife with rejection and humiliation (Wilkinson \& Pickett, 2009). Note that Akiba et al. (2002) have failed to find significant relationship between the rates of school violence and income disparity (as measured by the Gini index). Finally, it should be mentioned that economists rarely investigate the ways in which economic deprivation can lead to youth violence. On the contrary, a number of sociological studies have pointed out some social and economic conditions as the roots of youth violence. For example, Cullen (1994) used the concepts of social support and informal social control to explain youth violence. Social support is defined as «the perceived or actual instrument and/or expressive provisions supplied by the community social networks, and confiding partners» (p. 530). The lack of social support or the breakdown of informal social control has also been cited by criminologists as a factor in the involvement of persons in criminal behaviour. Informal social control involves all the sanctions and constraints used in order to make an individual con- 
form to social norms. Cullen (1994) also points out that «economic inequality can generate crime not only by exposing people to relative deprivation but also by eviscerating and inhibiting the development of social support networks» (p. 534). In his review of the research on the connections between family deprivation and violent crime, Currie (1998) cites four important results. First, extreme deprivation inhibits children's intellectual development. Second, extreme deprivation breeds violence by encouraging child abuse and neglect. Third, extreme poverty creates multiple stresses that undermine parents' ability to raise children caringly and effectively. Fourth, poverty breeds crime by undermining parents' ability to monitor and supervise their children. In conclusion, these results suggest that redistributing wealth and creating more egalitarian societies would reduce the amount of youth violence.

\section{Social integration, violence and school violence}

The relation between social integration and school violence has also been investigated by sociologists. Social integration has been mainly measured by divorce rate and the percentage of minorities in the studies of homicide. Divorce is likely to reduce parental social capital (Coleman, 1988). The latter concept refers to the time and effort parents devote to their positive interactions with their children, other parents, and school personnel. A number of studies have demonstrated that children who are not adequately attached to their parents are at high risk for violence (Amodei \& Scott, 2002). In addition, family dissolution often lowers the living standards for children and that increases the likelihood of violence. Furthermore, several authors have hypothesized a relationship between cultural diversity and school violence. Where high divorce rate and cultural diversity exist, social relations become more impersonal and anonymous and social controls become weak, which may result in higher rates of crime and delinquency (Akiba, Le Tendre, Baker \& Goesling, 2002). Also, they predicted that culturally heterogeneous societies may have higher crime rates because dominant group norms proscribe the behaviours valued by minority cultural groups. Consequently, cultural diversity can lead to cultural conflict and increased inter-group violence. It is worth noting, however, that empirical evidence does not strongly support these claims. For example, Wolke, Woods, Schulz, and Stanford (2001) cite a substantial amount of studies concerning the ethnicity of children or ethnic mix of the schools that found no significant relationship between ethnic minority status and bullying rates in different countries. Gottfredson and Gottfredson (1985) found a high minority concentration to be related to individual interpersonal violence, but mentioned that the majority of studies have found no effect of the racial and ethnic composition of a school on the amount of bullying.

\section{Crime rates and school violence}

TIMSS data have also been used by Akiba et al. (2002) to explore the amount of school violence among 37 nations that included both developing and developed 
countries. Their results show that school violence is not directly linked to overall levels of crime or deviance in a given society, but national systems of education that produce greater achievement differences between students tend to record more violence. Consequently, equalizing the quality of education for all students is seen as one possible remedy for school violence. These results contrast with those reported by Elliot, Hamburg, and Williams (1998), who considered that the level of school violence and other juvenile delinquencies are reflections of crime rates in the society. McGarvey, Smith, and Walker (2007) investigate the link between school outcomes and both school and neighbourhood measures of violence using individual data from the High School and Beyond Survey. Their study's policy relevance arises from the new funding requirements implemented in No Child Left Behind Act (NCLB). The NCLB is the first U.S. federal law that explicitly focuses on student behaviour and requires the prevention of school violence as a condition of receiving federal funding. The results indicate that both in-school violent crimes and the neighbourhood violent crime rate have strong negative effects on school performance as measured by the proportion of students at each school who meet or exceed state standards on standardized tests. The literature also appears to support the theory that violence begets violence. In a study of over 2,000 elementary school-aged children, Singer et al. (1999) showed that exposure to violence in the past year was the most significant contributor to predicting violent behaviour even after controlling for child demographics, parental monitoring and television viewing habits. According to Song, Singer and Anglin (1998), violence exposure and symptoms of psychological trauma together explained more than 50 percent of the variance in male and female self-reported violent behaviour. In the same vein, Widom (2000) estimated that up to 70 percent of violent adults have a history of violence, either as direct victims or as witnesses of interparental violence. Wilczenski et al. (1997) argue that being directly or indirectly victimized at home brings the child to «learn» this behaviour and signal to others that weakness has been learned and accepted as a stable personal trait. This is consistent with the «social learning theory» of Bandura (1973) according to which aggressive behaviour is learned rather than inborn. It is acquired and maintained primarily through observational learning and direct experience. For instance, children who witness their mothers being harassed, insulted, and beaten up by their partner, might learn that violence is a normal way of being treated.

\section{School size and violence}

School size is seen as a critical factor in determining educational outcomes. The observation that many acts of violence have arisen in large schools has led to a growing area of research on the relationship between school size and youth violence. The economics literature often argues that larger sized schools enjoy benefits through economies of scale (Kenny, 1982; Chakraborty et al., 2000; Hanushek, 1986). Leung and Ferris (2008) analyze the role of school size in relation 
to youth violence. They state that, within large-scale firms, low employee morale and high turnover rates are often the result of workers becoming alienated while working on repetitive specialized tasks. In the school context, students may experience alienation through their encounter with impersonal instruction and institutional indifference. Thus, students who require more time and attention may easily become frustrated, and the continuing neglect of their concerns combined with their inability to release frustration and stress in a socially acceptable manner may culminate in student violence. Note that, in the sociological literature, this explanation is in line with the Strain Theory in which delinquency is considered as a problem solving mechanism used by youths to deal with their frustration (Merton, 1938; Brezina, 1996). An example of study supporting the hypothesis of a causal relationship linking student anger and frustration to aggression in schools is Brezina et al. (2001). Many studies have also argued that students in larger schools experience greater isolation and become more alienated and frustrated than their counterparts in smaller sized schools (Cotton, 2000; Ferris \& West, 2002). Leung and Ferris (2008) examine the relationship between school size and youth violence using data collected from a group of young males living in Montreal, Quebec, in the 1990s. The dependent variable in the analysis is whether these youths self-report an act of violent behaviour when they were 17 years old. The explanatory variables include information related to their schools, their parents, and their peer influences. They find that factors such as growing up in a broken family, having delinquent friends, and attending a lower quality school can increase the marginal probability of violence from 13 percent to 23 percent. The analysis also suggests that any potential education gain that arises through larger scale may be achieved only at the cost of increasing level of student frustration, alienation, and violence. More specifically, Leung and Ferris find that a student attending a school with more than 2000 students is about 22 percent more likely to engage in an act of serious violence than a student who attends a school with less than 1000 students. Another study supporting the relationship between school size and delinquent behaviour is given in Ferris and West (2004) who use data from the U.S. National Center for Education Statistics (NCES). Their study shows that the percentage of schools reporting serious crime is as much as five times higher in schools with more than a thousand students. Researchers of the NCES also found that discipline problems are often related to school enrollment size. Large schools tended to yield more discipline problems than small schools. For example, their results show that 34 percent of schools with 1000 or more students reported student disrespect for assaults on teachers at least once per week, compared with 21 percent of those at schools with 500-999 students, 14 percent of those at schools with 300-499 students, and 7 percent of schools with less than 300 students (Indicators of School Crime and Safety, U.S. Departments of Education and Justice, 2005). A major drawback of some studies mentioned above concerns the way that the data are collected, in particular, the common use of school-based data, a 
source that may contain its own «selection bias». Specifically, school reported data may indicate that smaller schools exhibit less violence solely because their students are selected from a subset of less violent students. Finally, it is important to note that a number of studies have reported no relationship between school or class size and school violence (Whitney \& Smith, 1993; Mellor, 1999; Olweus, 1993), while others have found that small schools and classes have more violence (O’Moore et al, 1997; Wolke et al., 2001). One argument supporting the latter finding is that violence in school is often a group process, and in small schools and classes there are more confined spaces and fewer friendship choices and the group changes are less frequent (O’Moore et al, 1997).

\section{Psychosocial consequences of school violence}

There is an abundant psychological literature on the profiles of the aggressors/bullies and victims of school violence. For example, research shows that bullies are less interested in school than students not involved in bullying. In addition, both bullies and victims are more likely to experience feelings of loneliness and poor relationships with classmates than students not involved in bullying (see Nansel et al., 2001; Hodges, Malone, \& Perry, 1997). Moreover, victims of bullying often experience anxiety and depression, low self-esteem, physical and psychosomatic complaints. In extreme cases, they may commit suicide (Smith, Talamelli, Cowie, Naylor \& Chauhan, 2004).

\section{School violence and educational outcomes}

Currently, school violence research is attracting increasing interest in the economics literature. One issue that has received special attention in the economics literature is the relation between violence and educational achievement or outcomes. School violence is expected to have an adverse effect on pupil performance because it can create important disruptions within an education environment, reducing the effectiveness of classroom teaching time. It also can inhibit the educational process by causing individual students and parents to be more concerned about the safety of school environment than the material being taught, distracting from the goal of educational performance. Methodologically, to explore the effect of school violence on student attainment, the most common empirical approach used consists to estimate the following equation: ij $y=i j X \beta+s v_{j} \gamma s+$ $n j v \gamma_{n}+j c \delta+i j u, i=1, \ldots, n j ; j=1, \ldots N$. where the dependent variable $i j y$ represents the educational attainment of the $i$ th student in the $j$ th school. Vector $X_{i j}$ includes individual-specific regressors. The vector v s $\mathrm{j}$ contains the measures of violence in the jth school, the vector $\mathrm{v} n j$ contains measures of neighbourhood violence pertaining to the $j$ th school, and the vector $c j$ contains all other school- 
specific factors. The term $u$ ij is an unobservable disturbance term, assumed to have zero mean and to be independent across students in different schools. The number of individuals in the $j$ th school is $n_{j}$; there are $\mathrm{N}$ schools in the sample. The terms $\beta, \gamma_{s}, \gamma_{n}$, and $\delta$ are the regression coefficients to be estimated. In particular, $\gamma_{s}$ gives the effect of school violence on student performance, and $\gamma_{n}$ gives the effect of neighbourhood violence, controlling for all the variables included in ij $X$ and $j$. Ideally, one would like to have data on neighbourhood violence in order to estimate the effects of school and neighbourhood violence separately. Estimating the effects of school violence raises several simultaneity problems (Grogger, 1997). For example, the level of violence in a school may be correlated with the overall level of disorder, or with a «bad school» effect more generally. Without controlling for factors that contribute to the bad school effect, a regression model would attribute to school violence part of the effect actually due to those other factors, overstating the effects of school violence per se. Another concern is that the question of whether the effects of violence in the school can be distinguished from the effects of violence in the neighbourhood. In a system of neighbourhood schools, this distinction is difficult to make.

\section{Absenteeism}

There is important evidence in the economics literature to support the adverse effect of absenteeism on educational attainment. Absenteeism from school is commonly associated with school violence. As already mentioned, some of the prior research assumes that students who fear attack at school, or who have been attacked, are more likely to stay at home for reasons other than illness (Grogger, 1997; Pearson \& Toby, 1991). For example, the U.S. National Center for Education Statistics indicates that 6 percent of American students avoided a school activity in the previous six months due to fears of attack or harm (NCES, 2006). In a review of the literature, Dake, Price, and Telljohann (2003) also found that victims of school violence display higher rates of absenteeism than their peers. Glew et al. (2005) have produced evidence that students who have been bullied are 2.1 times more likely than other students to feel unsafe at school and 20 percent of U.S. elementary school students would reportedly skip school to avoid being bullied. School absences caused by feeling unsafe are also documented by Rigby (1998), who found that approximately 16 percent of boys and 31 percent of girls reported being absent from school in attempts to avoid being victimized.

\section{Educational attainment and Labour market outcomes}

In the same vein, students concerned for their safety may also have difficulty concentrating. Consequently, their achievement and advancement may suffer (Grogger, 1997). In his article, Grogger examines how local violence affects high school graduation and college attendance. He uses data from the High School and Beyond Survey, a major longitudinal study of American youth, and finds that local violence has important effects on student achievement. In particular, Grog- 
ger finds that moderate levels of violence reduce the likelihood of high school graduation by 5.1 percentage points on average, and lower the likelihood that a student will attend college by 6.9 percentage points. The author also talked about school violence as an argument to bolster the argument of schools choice. Because of exposure to violence, students may attend non-violent schools to leave the areas in which they reside. Bosworth (1994) also uses data from a major longitudinal research, the Youth Cohort Study of England and Wales (YCS), to evaluate the effect of truancy on educational attainment. He finds that higher levels of attainment are linked with the desire of students to be in school, and that, violence issues are symptomatic of poor students attitudes towards education. Brown and Taylor (2008) conduct an econometric analysis of the effects of bullying on human capital accumulation over an individual's lifecycle. They exploit the rich data available from the British National Child Development Study (NCDS). With NCDS data, one can relate a child's experience of bullying at school to his subsequent educational attainment and wages received during various stages of adulthood. The findings suggest that school bullying has an adverse effect on human capital accumulation both at and beyond school. They also find that being bullied at school influences wages received during adulthood as well as indirectly influencing wages via educational attainment. Le, Miller, Heath, and Martin (2005) examine how childhood disorder problems influence schooling and labour market outcomes. They find two behavioural problems that have the largest negative impacts on the decision to leave school for both males and females: namely, bullying activity and a propensity for starting physical fights. Two possible pathways through which conduct disorder might have an impact on labour market outcomes are considered in their study. First, it is possible that childhood conduct disorder will alter the chances that a person will be employed. Second, among those who are employed, childhood conduct disorder may impact on the wage obtained. Using longitudinal data on a cohort of high school graduates, Waddell (2006) shows that U.S. youth who reveal poor attitude and self-esteem attain fewer years of postsecondary education, are less likely to be employed, and realise lower earning. Being bullied at school may be associated with negative attitudes and low self-esteem (Brown \& Taylor, 2008). Ammermueller (2007) evaluates the degree of school violence in 11 European countries and analyzes the determinants of being a victim and its effect on student performance. He uses data from the Trends in International Mathematics and Science Study (TIMSS) 2003 and the NCDS. The latter allows for a more credible identification of the effect and provides controls for prior achievement, prior victimization and additional student characteristics. The results show that the behaviour of peers in the form of school violence is an important determinant of both contemporary and later student achievement. He also finds that being bullied as a child has a significant impact on the level of educational attainment and labour market earnings. Hence, reducing violence at schools not only eases life for many students who suffer from it but should also lead to more invest- 
ment in human capital. Varhama and Björkqvist (2005) study the link between being bullied at school in adolescence and long term unemployment in adulthood in Finland. They find that, among individuals with long term unemployment problems, 29 percent responded that they had been exposed to bulling at least once per week during adolescence. The association between bullying behaviour and academic achievement was also investigated by Woods and Wolke (2004), who argue there has been a dearth of research focusing on this issue. In their study, 1016 children from U.K. primary schools were individually interviewed about their bullying experiences. Surprisingly, they found little evidence of a direct link between being a bully and erosion of academic achievement.

\section{Conclusion}

Modelling the causes and consequences of violence in schools is complex and has not been a primary focus for economists. Because concern about the phenomenon has increased in recent years, however, school violence research is attracting increasing interest in the economics literature. This paper gives an overview of the main issues about school violence mainly from an economic perspective.

The heterogeneity across studies makes them difficult to summarize succinctly. Nevertheless, the review shows that the phenomenon has an adverse effect on human capital accumulation both at and beyond school. It also influences wages received during adulthood as well as indirectly via educational attainment. Hence, reducing violence at schools should lead to more investment in human capital. These results suggest that economists should take account of this kind of variable when estimating educational production functions, but given the complexity of the phenomena, there is a need for communication with psychologists and other social scientists. Their knowledge and experience can help economists to identify the best ways to model the process of violence in schools. Because economists have begun only recently to analyse school violence, there remains ample room for additional studies. For example, an important area for future research involves further elucidation of the effects of school organization and climate (e.g., clarity of rules, sense of community, perceived fairness, social interactions among members, teacher involvement) on the level of problem behaviour. There is little economic-oriented research available concerning these factors. It would be helpful from a policy perspective to know the extent to which these malleable school organisational characteristics predict the level of violence in schools, compared to the role of structural or exogenous characteristics that are largely beyond the control of the school.

Although remarkable knowledge has been assembled regarding the role of economic deprivation in school violence, little is known about the dynamic aspects of the phenomenon. Future studies should attempt to examine the nature of trends in youth violence. There is a need, for example, to know if violence 
rates are counter-cyclical: that is, does stagnant economic activity raise violence rates? The increasing availability of longitudinal data has greatly enhanced the capacity of economists to answer such questions. Lastly, there is a dearth of research dealing with the possible causal pathways between school violence and student achievement and the direction of causality. In other words, does being involved in violence contribute to the prediction of educational achievement or alternatively, does poor academic achievement predict involvement in violence? Finally, in order to counter the adverse effects of violence in schools, it is apparent that teachers need to be better informed regarding the problem through their training programmes. It is hoped that, with training, every teacher can become a driving force in preventing and countering violence in schools.

\section{Acknowledgements}

This paper was part of a larger research project conducted when the author was visiting researcher at IREDU (Institute for Research on Economics and Sociology of Education), Dijon, France. The author wishes to thank, Bruno Suchaut and the institution for providing an excellent work environment. Thanks are also due to Francoise Alsaker and two anonymous reviewers for their constructive comments and suggestions. All errors and omissions are the sole responsibility of the author. Finally, note that an earlier version of this paper was presented at the 11th International Conference on Education sponsored by ATINER, May 25-28, 2009, Athens Greece.

\section{References}

Aalsma, M. \& Brown, J. (2008). What is Bullying? Journal of Adolescent Health, 43, 101-102. Akiba, M., LeTendre, G., Baker, D. \& Goesling, B. (2002). Student victimization: National and school system effects on school violence in 37 nations. American Educational ResearchJournal, 39 (4), 829-853.

Alsaker, F. D. (2003). Quälgeister und ihre Opfer. Mobbing unter Kindern - und wie man damit umgeht. Bern: Huber Verlag.

Ammermueller, A. (2007). Violence in European schools: Victimization and consequences, ZEW Discussion Paper No. 07-004. Mannheim: Centre for European Economic Research.

Amodei, N. \& Scott, A. A. (2002). Psychologists'contribution to the prevention of youth violence. The Social Science Journal, 39, 511-526.

Bandura, A. (1973). Aggression: A social learning analysis. Englewood Cliffs, NJ: Prentice Hall.

Becker, G. S. (1968). Crime and punishment: An economic approach. Journal of Political Economy, 76, 169-217.

Bound, J. \& Freeman, R. (1992). What went wrong? The erosion of relative earnings andemployment among young black men in the 1980s. Quarterly Journal of Economics, 107, 20132.

Bosworth, D. (1994). Truancy and pupil performance. Education Economics, 2, 243-265.

Brezina, T. (1996). Adapting to strain: an examination of delinquent coping responses. Criminology, 34, 39-60.

Brezina, T., Piquero, A. R. \& Mazerolle, P. (2001). Student anger and aggressive behavior in school: an initial test of Agnew's macro-level strain theory. Journal of Research in Crime and Delinquency, 38(4), 362-386.

Brown, S. \& Taylor, K. (2008). Bullying, education and earnings: Evidence from the National Child Development Study. Economics of Education Review, 27, 387-401. 
Chakraborty, K., Basudeb, B. \& Lewis, C. (2000). Economies of scale in public education: An econometric analysis. Contemporary Economic Policy, 18, 238-247.

Coleman, J. S. (1988). Social Capital in the Creation of Human Capital. American Journal of Sociology, 94, 95-120.

Coleman, J. S, Campbell, E., Mood, A., Weinfeld, E., Hobson, C., York, R. \& McPartland, J. (1966). Equality of educational opportunity. Washington D.C: U.S. Government Printing Office.

Cotton, K. (2000). School size, school climate, and school performance, closeup \#20. School Improvement Research Series. Northwest Region Education Laboratory.

Cullen, F. T. (1994). Social support as an organizing concept for criminology : Presidential address to the Academy of Criminal Justice Sciences. Justice Quarterly 11, 527-559.

Currie, E. (1998). Crime and punishment in America. New York: Pantheon.

Dake, J. A., Price, J. H. \& Telljohann, S. K. (2003). The nature and extent of bullying at school. Journal of School Health, 73 (5), 173-180.

Dolan, R. C. \& Schmidt, R. M. (1987). Assessing the impact of expenditure on achievement: Some methodological and policy considerations. Economics of Education Review, 6, 285-299.

Elgar, F.J., Criag, W., Boyce, W., Morgan, A. \& Vella-Zarb, R. (2009). Income Inequality and School Bullying: Multilevel Study of Adolescents in 37 Countries. Journal of Adolescent Health (forthcoming).

Elliot, M. \& Kilpatrick, J. (1994). How to stop bullying: A Kidscape Training Guide. London: Kidscape.

Elliott, D. S., Hamburg, B. A. \& Williams, K. R. (1998). Violence in American schools: An overview. In D. S. Elliott, B. A. Hamburg \& K. R. Williams (eds.), Violence in American schools (pp. 3-28). New York: Cambridge University Press.

Farrell, D. A. \& Flannery, D. J. (2006). Youth violence prevention: Are we there yet? Aggression and Violent Behavior, 11, 138-150.

Ferris, J. S. \& West, E. G. ( 2002). Education vouchers, dropouts and the peer group problem. Southern Economic Journal, 68, 774-793.

Ferris, J. S. \& West, E. G. (2004). Economies of scale, school violence, and the optimal size of schools. Applied Economics, 36, 1677-1684.

Gartner, R. (1990). The victims of homicide: A temporal and cross-national comparison. American Sociological Review, 55, 92-106.

Glew, G.M., Fan, M.Y., Katon, W., Rivara, F.P. \& Kernic, M.A. (2005). Bullying, psychosocial adjustment, and academic performance in elementary school. Archives of Pediatrics and Adolescent Medicine, 159, 1026-31.

Gottfredson, G.D. \& Gottfredson, D.C. (1985). Victimization in Schools. New York: Plenum.

Grogger, J. (1997). Local violence and educational attainment. Journal of Human Resources, 32, 659-682.

Hanushek, E. A. (1986). The economics of schooling: Production and efficiency in public

schools. Journal of Economic Literature, 24, 1141-1177.

Hanushek, E. A. (1997). Assessing the effects of school resources on student performance: An update. Educational Evaluation and Policy Analysis, 19, 141-164.

Henry, S. (2000). What Is School Violence? An Integrated Definition. Annals of the American Academy of Political and Social Science, 567, 16-29.

Hodges, E. V. E., Malone, M. J. \& Perry, D. G. (1997). Individual risk and social risk as interacting determinants of victimization in the peer group. Developmental Psychology, 33, 1032-1039.

Hsieh, C. \& Pugh, M. (1993). Poverty, income inequality, and violent crime: A meta-analysis of recent data studies. Criminal Justice Review, 18, 182-202.

Janosz, M., Archambault, I., Pagani, L. S., Pascal, S., Morin, A. J. S. \& Bowen, F. (2008). Are there detrimental effects of witnessing school violence in early adolescence? Journal of Adolescent Health, 43 (6), 600-608. 
Kennedy, B. P., Kawachi, I. \& Prothrow-Stith, D. (1996). Income distribution and mortality: cross section ecological study of the Robin Hood index in the United States. British Medical Journal, 312, 1004-1007.

Kenny, L. W. (1982). Economies of scale in schooling. Economics of Education Review, 2, 1-24.

Le, A.T., Miller, P. W., Heath, A.C. \& Martin, N. (2005). Early childhood behaviours, schooling and labour market outcomes: Estimates from a sample of twins. Economics of Education Review, 24, 1-17.

Leung, A. \& Ferris, J. F. (2008). School size and youth violence. Journal of Economic Behavior \& Organization, 65, 318-333.

Mellor, A. (1999). Scotland. In Smith P.K. et al (eds.), The Nature of School Bullying: a crossnational perspective. London : Routledge.

Merton, Robert. (1938). Social structure and anomie. American Sociological Review, 3, 672-682.

McGarvey, M. G., Smith, J. \& Walker, M. (2007). The Interdependence of School Outcomes and School and Neighborhood Crime. Andrew Young School of Policy Studies Research Paper Series No. 07-19.

Nansel, T. R., Overpeck, M., Pilla, R. S., Ruan, W. J., Simmons-Morton, B. \& Scheidt, P. (2001). Bullying behaviors among U.S. youth: Prevalence and association with psychosocial adjustment. Journal of the American Medical Association, 25, 2094-2100.

Olweus, D. (1993). Bullying at school: What we know and what we can do. Oxford: Blackwell.

O'Moore, A.M., Kirkham, C. \& Smith, M. (1997). Bullying behaviour in Irish schools: nation-wide study. Irish Journal of Psychology. 18, 141-169.

Pearson, F. S. \& Toby, J. (1991). Fear of school related predatory crime. Sociology and Social Research, 75, 117-125.

Rigby, K. (1998). The relationship between reported health and involvement in bully/victim

problems among male and female secondary schoolchildren. Journal of Health Psychology, 3, 465-476.

Sabates, R. (2008). Educational attainment and juvenile crime. British Journal of Criminology, 48, 395-409.

Singer, M., Miller, D.B., Guo, S., Flannery, D.J., Frierson, T. \& Slovac, K. (1999). Contributors to violent behaviour among elementary and middle school children. Pediatrics, 104, 878-884.

Smith, P. K., Pepler, D. \& Rigby, K. (eds.) (2004). Bullying in Schools: How Successful Can Interventions Be? Cambridge: Cambridge University Press.

Smith, P. K., Talamelli, L., Cowie, H., Naylor, P. \& Chauhan, P. (2004). Profiles of nonvictims, escaped victims, continuing victims and new victims of school bullying. British Journal of Educational Psychology, 74, 565-581.

Song, L., Singer, M. \& Anglin, T. (1998). Violence exposure and emotional trauma as contributors to adolescents' violent behaviors. Archives of Pediatrics and Adolescent Medicine, 152, 531-536.

The Average Teacher (2002). Teacher Magazine (November/December ), 30.

U.S. Department of Education, National Center for Education Statistics (2006). Digest of Education Statistics, 2005. (NCE 2006-030). Washington, DC: U.S. Department of Education

U.S. Department of Education (2007). Annual report on school safety. Washington, DC: U.S. Department of Education.

Varhama, L. \& Björkqvist, K. (2005). Relation between school bullying during adolescence and subsequent long term unemployment in adulthood in a Finnish sample. Psychological Reports, 96, 269-272.

Waddell, G. (2006). Labor-market consequences of poor attitude and low self-esteem in youth. Economic Inquiry, 44, 69-97.

Widom, C. (2000). Childhood victimization: Early adversity, later psychopathology. National Institute of Justice Journal, 1, 2-9. 
Wilczenski, F. L., Steegmann, R., Braun, M., Feeley, F., Griffin, J., Horowitz, T. \& Olson, S. (1997). Children as victims and victimisers. Intervention to promote «Fair Play». School Psychology International, 18, 81-89.

Wilkinson, G., Pickett, K. E (2009). The Spirit Level: Why More Equal Societies Almost Always Do Better. London: Penguin.

Whitney, I. \& Smith, P. K. (1993). A survey of the nature and extent of bullying in junior/middle and secondary schools. Educational Research, 35(1), 38-47.

Wolke, D., Woods, S., Schulz, H. \& Stanford, K. (2001). Bullying and victimisation of primary school children in South England and South Germany: Prevalence and school factors. British Journal of Psychology, 92, 673- 696.

Woods, S. \& Wolke, D. (2004). Direct and relational bullying among primary school children and academic achievement. Journal of School Psychology, 42, 135-155.

Key words: School violence, Bullying, education economics, human capital, student achievement

\section{Gewalt an Schulen: einige Resultate aus der Wirtschaftsliteratur}

\section{Zusammenfassung}

In den letzten zwanzig Jahren ist die Gewalt an Schulen zu einem ernsten sozialen Problem geworden. So haben Forscher, Forscherinnen und Entscheidungsträger beschlossen, die Gründe und Konsequenzen zu erfassen und wirkungsvolle Mittel einzusetzen, damit die Ausweitung des Übels verringert werden kann. Soziologen, Psychologen und andere Sozialforscher beschäftigen sich seit langem mit diesem Phänomen, im Gegensatz zur volkswirtschaftlichen Forschung, die sich erst seit kurzem für die Gewalt an Schulen näher interessiert. Dieser Artikel gibt einen Überblick über die empirischen Kenntnisse zum Thema, ausgehend von ökonomischer Literatur und anderen ähnlichen Disziplinen. Die wichtigsten Resultate zeigen auf, dass die Gewalt an Schulen negative Auswirkungen auf die schulischen Erfolge haben, aber auch auf den Einstieg ins Erwerbsleben. Daher würde eine Reduktion dieser Art von Gewalt nicht nur die Lebensqualität der darunter leidenden Schüler verbessern, sondern auch das Investieren in menschliches Kapital begünstigen.

Schlagworte: Gewalt an Schulen, Quälereien, Erziehungsökonomie, Humankapital, Schulerfolg. 


\title{
La violence à l'école: quelques résultats issus de la littérature économique
}

\begin{abstract}
Résumé
Au cours des deux dernières décennies, la violence à l'école est devenue un problème social majeur. Ainsi, les chercheurs et les décideurs s'efforcent d'en comprendre les causes et les conséquences et de mettre en place des moyens efficaces pour réduire son ampleur. Les sociologues, psychologues et autres chercheurs en sciences sociales se penchent sur le phénomène depuis fort longtemps. Par contre, l'intérêt de la recherche économique pour la violence scolaire est très récent. Cet article se propose de passer en revue les connaissances empiriques sur ce thème à partir de la littérature économique et d'autres disciplines proches. Les principaux résultats montrent que la violence à l'école a des effets négatifs sur la réussite scolaire des élèves mais également sur leur insertion sur le marché du travail. Par conséquent, réduire la violence scolaire, améliorerait non seulement le bien-être des élèves qui en souffrent, mais favoriserait les investissements en capital humain.
\end{abstract}

Mots clés: Violence à l'école, harcèlement scolaire, économie de l'éducation, capital humain, réussite scolaire

\section{La violenza scolastica: risultati ottenuti dalla letteratura ecomomica}

\section{Riassunto}

Durante gli ultimi due decenni, la violenza scolastica è diventata un grave problema sociale. Per questo motivo, ricercatori e politici si sono impegnati nel tentativo di capirne le cause e le conseguenze e di identificare mezzi efficaci per ridurne la portata. Mentre sociologi, psicologi ed altri ricercatori in scienze sociali si dedicano al fenomeno da tempo, la ricerca economica si è interessata alla violenza scolastica solo di recente. Questo articolo si propone di passare in rassegna le conoscenze empiriche riguardanti il tema, a partire dalla letteratura economica ed altre discipline affini. I principali risultati mostrano che la violenza scolastica ha effetti negativi sulla riuscita scolastica degli allievi, ma anche sul loro inserimento nel mercato del lavoro. Di conseguenza, ridurre la violenza scolastica migliorerebbe non solo il benessere degli allievi che la subiscono, ma dovrebbe persino portare a un maggior investimento nel capitale umano.

Parole chiave: Violenza scolastica, bullismo, economia dell'educazione, capitale umano, riuscita scolastica 